Int. J. Electrochem. Sci., 11 (2016) $9100-9109$

\title{
Comparing the Air Flow Distribution Qualities Among Three Different Air Flow Path Configurations for Tubular Solid Oxide Fuel Cell Stacks
}

Zidong $Y u^{1,2, *}, Y u \mathrm{Xu}^{2}$, Biao $\mathrm{Hu}^{2}$, Shengji Liu ${ }^{1, *}$, Xinyi Zhang ${ }^{2}$

${ }^{1}$ School of Automobile and Traffic Engineering, Jiangsu University, Zhenjiang, Jiangsu 212013, China;

${ }^{2}$ School of Energy and Power Engineering, Jiangsu University of Science and Technology, Zhenjiang, Jiangsu 212003, China.

*E-mail: yuzidong@just.edu.cn

doi: $10.20964 / 2016.11 .12$

Received: 21 July 2016 / Accepted: 2 September 2016 / Published: 10 October 2016

In this paper, the air flow distribution quality within a conventional tubular solid oxide fuel cell (TSOFC) stack air flow path structure was analyzed by 3D calculating fluid dynamics (CFD) simulating. The air flow field within the T-SOFC stack was of a typically turbulence characteristic. Both air flow distribution qualities among $36 \mathrm{~T}$-SOFC units in stack level and over each T-SOFCs unit surface within the T-SOFC stacks with different air flow manifold configuration designs, such as lin1out-line, lin1out-Z, and 2in2out-Z type, were carefully compared through 3D simulation. 2in2out-Z type air flow path structure was concluded to be a more suitable chooses for T-SOFC stack, because its smaller variation of $\mathrm{x}$-velocity at each main plane than that in other type air flow path structures.

Keywords: Tubular SOFC stack, air flow distributing path optimization, turbulence flow characteristic.

\section{$\underline{\text { FULL TEXT }}$}

(C) 2016 The Authors. Published by ESG (www.electrochemsci.org). This article is an open access article distributed under the terms and conditions of the Creative Commons Attribution license (http://creativecommons.org/licenses/by/4.0/). 